Paper received: Sep 152020

Paper accepted: Feb 192021

\begin{tabular}{|r|rc|}
\multirow{2}{*}{ Original paper } & Olivera D. Cekić-Jovanović ${ }^{1}$, Snežana P. Marković \\
\cline { 2 - 4 } & University of Kragujevac, Faculty of Education \\
Jagodina, Republic of Serbia
\end{tabular}

\title{
Possibilities of University Teaching Enhancement - Integration of Methods and Approaches in Teaching Literature with Science and Social Studies ${ }^{2}$
}

\begin{abstract}
Summary: Starting from the established standards and requirements for ensuring the quality of university teaching, via improving and modernizing the teaching process by applying innovative teaching methods, conditions are met for raising the quality of working with students. Integration of the teaching content and application of an integrative approach represent a way of enhancing the quality of the teaching process. The theoretical part of this paper presents the advantages and examples of the integration of the Literature Teaching Methodology and Science and Social Studies Teaching Methodology curriculum content. In order to practically implement the theoretical context for the development of this idea, we examined the views of students at the Faculty of Education, i.e. future teachers $(N=150)$, regarding the integration of teaching approaches to teaching Literature and Science and Social Studies as opportunities for enhancing the quality of university education. Descriptive and scaling methods were used in the empirical part of the research. The results of the research have confirmed that students recognize the benefits of integrative teaching and its importance for their future professional engagement; they expect to cooperate with teachers and students in the preparation and realization of integrative classes; and they define the integration of methodological content as the premise of quality for the acquired knowledge at the faculty, and see it as one of the preconditions for a better understanding of the subject matter they adopt in the teaching process. The latter statement underscores the conclusion that the application of integrative teaching represents a good starting point for ensuring the quality of higher education following the European standards.
\end{abstract}

Keywords: higher education quality, integrative teaching, teaching process innovation, studentcentered learning, teaching methodology.

\footnotetext{
1 o.cekicjovanovic@gmail.com

2 The paper is a result of working on a bilateral project entitled Assumptions and Possibilities of Developing Innovative Teaching Models Functioning to Achieve Transparency of University Education and Raising Competitiveness on the Knowledge Market in the Country and Abroad, realized and financed by the Faculty of Education, University of Kragujevac, Jagodina (Republic of Serbia) and the Faculty of Education, University of Primorska, Kopar (Republic of Slovenia), (2017-2019).

Copyright $\odot 2021$ by the authors, licensee Teacher Education Faculty University of Belgrade, SERBIA.

This is an open access article distributed under the terms of the Creative Commons Attribution License (CC BY 4.0) (https://creativecommons.org/licenses/by/4.0/), which permits unrestricted use, distribution, and reproduction in any medium, provided the original paper is accurately cited.
} 


\section{Introduction}

The implementation of the Bologna Process has put the quality of higher education into the focus of reform changes with the aim of providing more competitive, higher quality and more efficient education for everyone, and contributing to the development of cooperation among various European countries and institutions (Forsman Svensson, 2004; Kristoffersen, 2010; Lisbon European Council..., 2000; Qiang, 2003). During the last decade especially, it was insisted that the higher education system be ready to respond to numerous demands, because dynamic changes in contemporary society require and, at the same time, condition the actualization of the provision and improvement of the quality of higher education. Modern times are characterized by dynamic changes, constant challenges, uncertainty, unpredictability of changes both in economy and society, resulting from technological innovations and globalization, which all led to a situation where the type of jobs and labor force today are significantly different from those in the past decades. Instead of some formerly popular ones, new jobs and occupations have emerged nowadays, which is why the Bologna Declaration points to the necessity of adapting tertiary education to the immediate needs of society, hence, European higher education institutions face great challenges in terms of changing institutional identity and understanding the essence of education and its role (Bodroski Spariosu, 2015: 410). The concept of contemporary university education highlights the establishment of the quality of teaching as one of the crucial responsibilities of higher education institutions (McKimm, 2009). Accordingly, there is a strong focus on curriculum reforms as processes that lead to a higher quality of education and more flexible and individualized educational approaches. All the above mentioned requires that higher education institutions direct maximum attention towards improving the quality of teaching at all levels of study (The Bologna Process 2020 - The European Higher Education Area in the New Decade,
2009). The Strategy of the Education Development in Serbia until 2020 sees the assumptions of the higher education quality in the equalization of the future teachers' training quality, holding lectures in joint subjects and teachers and students' mutual cooperation, as well as in the alignment of knowledge and skills with the National Qualifications Framework and key competences, such as: the ability to innovate, critical thinking, communication skills, etc.

These strategic documents represent a significant starting point for the development and implementation of numerous innovative teaching systems, including an integrative approach to university curriculum content, which can likewise be performed within higher education institutions in the European context.

\section{Integrative Approach in the University Teaching System}

Research and practical experience gathered so far (Satiansiriwiwat, Intorrathed, Siriwan, 2018; Aristya Putra, Kumano, 2018) have shown that an integrative approach can have multiple advantages for university teaching compared to traditional teaching models. The following advantages of crucial and paramount significance can be singled out: 1) the possibility of cooperation of two or more teachers, 2) focusing on the student as the center of the education process, and 3) knowledge quality and students' competences enhancement. At the level of university education, the benefits of an integrative approach lie in the mutual cooperation of university associates in planning and realizing classes, as proposed by The Strategy of the Education Development in Serbia until 2020. Integrative teaching is desirable since it brings about more favorable outcomes (Sawyer \& Rimm Kaufman, 2007) and positive changes in education resulting from teachers' awareness of the necessity for helping each other, engaging in conversation, exchanging experience and monitoring each other's teaching performance (Barth, 1999). If coop- 
eration is organized and implemented in a satisfactory manner, it is more likely that teachers might be able to influence the curriculum together, promote it, and thus increase the quality of teaching, which most often positively affects the overall achievement of students, i.e. pupils (Mirić, Đorović, 2015). However, the research conducted in Serbia and abroad (Forsman Svensson 2004; Mirić, Đorović, 2013; Van Naerssen \& Eastwood, 2001) demonstrates that such a cooperation mostly ends with a promised willingness for working together, yet seldom transforms into a continuous, institutionalized and everyday practice, whatsoever.

By further analysis, the advantages of an integrative approach to content-based teaching can be seen in the context of the student's position in the teaching process. Primarily, it enables an active participation of students in the teaching process. The aforementioned teaching model puts the student into the position of a researcher who is encouraged to find and devise connections between different teaching areas and subjects, by which they are practically included in the creation of the teaching process (Leisyte \& Westerheijden, 2014). Through this, one of the requirements of contemporary university education, to make the student the center of learning, is achieved. In addition to research competences, an integrative approach stimulates students' creativity, emphasizes the ability of divergent thinking, develops the ability of didactic processing of all types of texts and their adaptation to students' developmental and cognitive abilities, encourages and enhances the ability of interpretive reading as well as oral presentations (retelling, description, narration), and ensures better knowledge gained during classes. By means of an integrative approach, students of faculties of education - future teachers, are encouraged: to detect and apply different perspectives while observing; to connect facts; to think critically and creatively about diverse ideas; to process and discover information in various ways; to experience the content and create their original, individual work (Landi, 2007).
The Strategy of the Education Development in Serbia until 2020 underscores the significance of the development of divergent thinking, creative abilities and creative potentials of students, as well as practical knowledge in different fields. The strategy likewise highlights the importance of inter-subject planning and connecting the curriculum content. In order for students - future teachers to meet the preset demands, they need to possess the competences outlined in the Regulations on Continuous Professional Development and Academic Title Reception for Teachers, Educators and Associates (Official Gazette RS, 2012), related to the expert area (K1), teaching and learning (K2), support of the development of a child's and student's personality (K3), as well as communication and cooperation (K4). ${ }^{3}$

Insisting on the aforementioned competences aims to provide a higher quality teaching in which students will better understand and comprehend specific content, consider certain issues and problems from different perspectives and viewpoints, develop habits to see the phenomena, processes, and relationships in the environment more profoundly and comprehensively, and, thereby, create a singular image of the world that surrounds them (SpasićStošić, 2014: 502).

Having the previously mentioned in mind, in the present paper we will consider the possibilities of applying an integrative approach in the content presentation from the subjects Literature Teaching Methodology and Science and Social Studies Teaching Methodology, on a sample comprising the students of the Faculty of Education. Since the content of these methodologies is interdisciplinary, and based on didactic foundations, there are numerous possibilities for integration, beginning with teaching methods and approaches, teaching tools, etc.

Considering the goals and tasks of the Science and Social Studies Teaching Methodology, many authors (De Zan, 2005; Banjac, Vilotijević, 2009; Blagdanić, Banđur, 2018) emphasize that its main

3 http://katalog.zuov.rs/ StandardiKompetencija.aspx 
role is to introduce students to the theory and practice of teaching about nature and society, among other things. Accordingly, the relevant literature indicates that, within the framework of the methodology in question, students should be equipped, on the one hand, to plan and realize the classes of Science and Social Studies in elementary schools using teaching materials, media, facilities and resources of the natural and social environment in which the teaching takes place; and, on the other hand, to understand the peculiarity of pupils' perceptions of different phenomena in nature and society. Although it has primarily been regarded as the scientific discipline dealing with the study of the theory and practice of the Serbian Language and Literature teaching, the Methodology of this subject represents an essential element of education to all teachers, because, without the knowledge of it and creative application of its methods, fundamental principles and procedures, a teacher cannot be regarded as an expert in the field. The Serbian Language and Literature Teaching Methodology is characterized by interdisciplinarity, investigative spirit, beyond-curriculum foundations and direct connection with other teaching areas related to class teaching. This is why it does not explore the existing teaching models only, but also seeks to find the teaching models that would enhance and modernize education in newly altered circumstances.

The common task of both methodologies is to introduce students, as future teachers, to teaching theory and practice, but also to present them with the necessity of designing an utmost successful model of activating students, both in cognitive, emotional and motivational terms, primarily due to the fact that teaching does not solely transfer knowledge, but attitudes, norms, values and emotions, as well.

The analysis of the curriculum content incorporated within Literature Teaching Methodology and Science and Social Studies Teaching Methodology indicates their interrelatedness, not only regarding the subject matter, included in the curriculum of elementary school subjects of Serbian and The World Around Us/Science and Social Studies, but also regarding the teaching approaches. Appreciable content can be integrated within the mentioned methodologies by linking different segments singled out by the principle of similarity, aiming for students guided by integration in teaching to get acquainted with different topics related to certain aspects of their environment via exploration. However, it should be noted that there is also the type of content that cannot be presented using this particular teaching model, but needs to be realized via different teaching systems. Bearing in mind that the concept of an integrative approach in teaching emphasizes a wholesome, intellectual, social, emotional and aesthetic development of students, and does not predominantly focus on isolated, cognitive aspects (Buljubašić-Kuzmanović, 2007: 148), we believe that the content, historical in character, could be appropriate for the implementation of the innovative teaching model in question. Taking all the previously mentioned into account, we will consider the possibility of integrating content pertaining to renowned historical figures in the context of the application of teaching methods studied within the given methodologies.

Some authors (Miller, Boix-Mansilla, 2004) believe that the levels of integration stem from a characteristic approach to scientific disciplines, their different analyses, and variable standard acceptability. In the Methodology of Science and Social Studies, historical subject matter is organized according to chronologically progressive, chronologically regressive, monographic and biographical models. In the teaching of Literature, the content is selected and organized according to topics, and they are arranged following readers' interests and age levels of students. The literary content from three literary genres (lyric, epic, drama), thematically structured in the readers and textbooks, usually represents a part of a larger whole (a collection of poems or stories, a novel), which means that sample texts are ex- 
cerpted from the original literary context. On the other hand, students are unfamiliar with both the time period and historical context in which a piece of literary work was created, which, especially when it comes to the examples of folk literature, negatively reflects on the level and quality of interpretation and comprehension of a particular piece. The readers are predominantly comprised of literary texts, authors' and folk literature, whose function is to draw students' attention to aesthetic and ethical values and models. Since these models are alterable and formed in line with social and historical circumstances, the context is an appreciable clue in understanding the actions of heroes in epic poems and the values they emphasize. Judging by experience, it is precisely due to the lack of these guidelines in thinking, that the analysis of a literary piece is reduced to a discussion about the piece, during which the discussion usually revolves around the way students would act more than it does around interpreting the reasons behind the actions of literary heroes.

During the classes it seems inevitable to shed light on the life and work of writers and scientists whose texts are read and interpreted, and the latter include: Saint Sava, Dositej Obradović, Vuk Stefanović Karadžić, Milutin Milanković, Nikola Tesla, Mihajlo Pupin. Since they represent the renowned figures in the history of the Serbian people, students learn about all of them during the classes of Science and Social Studies, which provides the possibility to functionally incorporate and connect literary, scientifically popular, and informative texts related to their life and work, and integrate them into the mentioned models of historical content organization. Thanks to the aforementioned types of texts, students upgrade the information provided by the Science and Social Studies textbooks to a wider knowledge of the famous historical figures, their interests, desires, the most important events in life, the people who affected their attitudes and actions to the greatest extent, as well as of the particular period in time, i.e. social and historical circumstances, making the overall perspective clearer and more substantial, impressive and comprehensive. With their imagery, suggestiveness and narrative forms, literary pieces provide an opportunity for students to create a wider and more convincing image of a certain historical period and events that they will remember. Students realize that for a full sense of accomplishment in an individual, their personal engagement, but also social, economic, and cultural circumstances in which they live, are of equal importance. Content integration produces the interaction of knowledge and experience - historical facts are complemented by emotional experiences and form personal experience that promotes social and emotional development of students, a "missing piece" in contemporary education (Tošić-Radev, Pešikan, 2017).

Thus, we can integrate the content according to time periods, historic events, renowned historical figures, but then the issue of methodology arises as the next level of integration planning. In both scientific disciplines, the monologue and text analysis methods are present, which is of fundamental importance when applying the integrative approach to historical content. The singularity of the monologue method in analyzing historical content lies in the need to emotionally and intellectually prepare students for the next segments of the class, via narrating. In the teaching of Literature, as well, the need for students to get acquainted with the social and historical context of the life and work of writers, requires the application of the monologue method, i.e. narration, by means of which students are motivated to read and prepare for the analytical and synthetic approach to a literary piece. The monologue method provides students with the opportunity to structure, i.e. didactically analyze the collected and examined material and thus adapt it to the teaching goals, and then choose the most suitable form of their own presentation in the form of narrating, describing, reporting or explaining (evidence, comparison, analysis, discussion and synthesis). Along with providing information, all these forms aim to 
motivate students for further engagement and provoke an emotional experience.

The text analysis method imposes itself as the other significant element in content integration. In the teaching of Science and Social Studies, text appears primarily as textbook content, whose function is providing information to students and being a source of knowledge. In addition to these texts, the Science and Social Studies Teaching Methodology dedicates special attention to the texts that may play a motivational role in the teaching process, as well as to the texts that are used to illustrate the presented content, prevailingly consisting of literary texts.

Along with literary texts, in Literature teaching, there is also a need for historical, literary-historical and popular texts. Unlike the literary texts in which one prevailingly seeks for aesthetic and ethical values, the aforementioned texts are read and analyzed in order to identify and extract information that would help understand the literary text. These texts are generally too extensive to be used as a whole, and moreover, there is a possibility of combining smaller excerpts from multiple texts, which all underlines the need to didactically analyze them in order to adjust them to their function in class the latter being the motivation for reading, interpreting and understanding the literary text. Special attention should be devoted to content presentation forms during the class. Regardless of the form (narration, retelling, description, etc.), the presentation should evoke interest, as well as positive emotional response in students. Certain segments could be displayed authentically, which underscores the need to adapt the reading mode to the nature of the text itself and to emphasize important facts and conclusions via interpretative reading.

\section{Methodology}

The current situation, as well as legal regulations that clearly emphasize the significance of integrative teaching, indispensably entail the need for taking the improvement of university teaching into consideration, especially the part dealing with the education of future teachers. Having in mind that students' perception is regarded as a very important resource, whose feedback, opinions and educational experience considerably contribute to the promotion of the quality of teaching and learning conditions at a higher education institution (Jevremov et al., 2016), their attitudes pertaining to integrative teaching which should play an important role in the system of university education should not be disregarded, because it is precisely these future teachers who will be able to carry out teaching in accordance with the The Law on the Fundamentals of the Education System (Official Gazette RS, no. 88/17) in the near future.

Having the previously presented theoretical background on integrative teaching in mind, we determined the aim of the research - examining the attitudes of students of the Faculty of Education (hereinafter FOE), i.e. future teachers, related to the integration of methodological approaches to teaching Literature and Science and Social Studies as opportunities for improving the quality of university education. Taking this particular aim into consideration, the following specific goals were outlined:

1. To determine whether FOE students recognize the advantages of integrating methodological approaches to teaching Literature and Science and Social Studies in the teaching process at the faculty, in terms of efficiency, role model learning and the position of the student;

2. To examine student expectations in relation to cooperation with professors and other students when preparing and applying the integration of Literature and Science and Social Studies curriculum content;

3. To determine whether students define the integration of methodological approaches to teaching Literature and Science and Social Studies as a premise of the quality of 
acquired knowledge in the teaching process at the faculty and a way for a better understanding of the content they adopt.

The research was based upon a descriptive method, including a survey by means of which the data were collected using a questionnaire, an instrument composed of a five-point Likert scale and open-ended questions. Future teachers - students of the Faculty of Education, University of Kragujevac, Jagodina, participated in the study. The survey was conducted in October and November 2017 with students of the Teacher $(\mathrm{N}=150)$ study program. The obtained data were analyzed using the statistical package IBM SPSS Statistics 20, and in accordance with the proposed goals of the study, the applied method and instrument, we applied the appropriate statistical testing procedures (percentage, frequency, median).

\section{Results and Discussion}

Following the proposed research questions of the study, we will present the results of the analysis of the collected data. In order to fulfill the first research task, the attitudes of students of the Faculty of Education were examined, especially the ones regarding the advantages of methodological approaches of Literature and Science and Social Studies teaching, in terms of efficiency, role model learning and the position of the student in the teaching process.

Regarding the advantages of the integrative model in terms of efficiency, as much as $89,67 \%$ of respondents believe that the approach saves time for analyzing certain teaching content by means of which the principle of efficiency is achieved, while students and pupils are concurrently relieved of learning excessive and unnecessary data. 9,33\% of students are indecisive, while $2 \%$ of respondents disagree with the statement. The obtained results of the research confirm the findings of previous theoretical considerations of various authors, emphasizing that the fundamental presupposition for the successful rationalization and efficiency in teaching lies in the ability of a teacher to attain most favorable results with the smallest possible amount of time, tools and effort, via a high level of methodological demise (Blagdanić, Banđur, 2018).

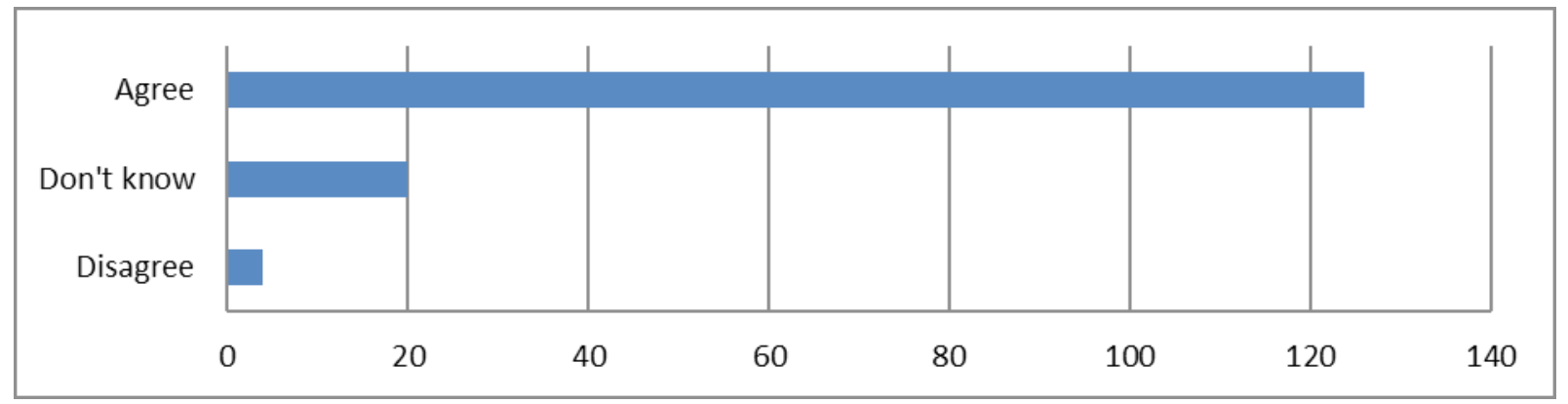

Figure 1. The Application of Integrative Teaching at the Faculty Enables Role Model Learning,

Hence the Easier and More Successful Application of the Model on Working with Primary School Students

Based on the obtained results (Figure 1) we notice that the majority of students (a total of 126, representing $84 \%$ ) positively regard and agree with the claim that the benefits of applying content integration of Literature and Science and Social Studies in university education are reflected in the role model learning, as well. Through this methodological approach students have the opportunity to familiarize themselves with the basic principles of integrative teaching, and to make the adopted working models easier to apply and adapt to their future work with pupils of elementary schools, based on specif- 
ic examples of integration of Literature and Science and Social Studies. The majority of respondents (128 students, $85.33 \%$ ) agree that the specific examples of interpretive reading and exchange of experience with colleagues - students and professors, facilitate easier adoption of methodologies, thereby the successful implementation of integrative instruction in the future._It goes without saying that the students of the faculties of education are presented with a significant task, i.e. the need to introduce pupils to the most important phenomena, states and processes, and enable them to understand the laws in nature and society, as well as to literary works belonging to the national and world heritage, appropriate to their age and cognitive development, making it possible for pupils to read and interpret them. In order to achieve the aforementioned goals, it is necessary, first and foremost, to prepare students of faculties of education for successful implementation of integrative teaching, because it primarily depends on their expertise, didactic and methodological, as well as pedagogical and psychological competence, preparedness, motivation and creativity (Spasić-Stošić, 2014: 501). The best way to attain this is to be exposed to a concrete example of the realization of the content of these methodologies within university teaching. The experience gathered thus represents an invaluable basis for working with pupils in elementary schools.

Considering the aspect of the student's position in the teaching process, the results of the research show that the majority of students $(=105$ (70\%)) feel that the advantage of integrative teaching can be seen in the fact that a student can assume an active role as a researcher, as well. The position of a researcher is important because it changes the perspective from which the student observes the lessons - it is no longer a pre-given task, but one's own independent choice from a multitude of options, which simultaneously implies a greater degree of responsibility and commitment. It seems especially significant that integrative teaching, especially at pedagogical faculties, enables a more active participation of students in their own personal education process and attainment of the leading position through independent decision-making, participation in the curriculum design, taking responsibility for one's own education, as well as active participation in teaching through research of teaching programs and their content, teaching approaches, teaching methodology (methods, principles and work modes), and the subject matter that is not included in programs, but could serve as a functional addition.

Bearing in mind that integrative teaching is fundamentally based on active teaching and learning, assuming a high quality communication, interaction and diverse mutual activities, with the aim of developing critical thinking, creativity, flexibility, and other prerequisites for living and working in the $21^{\text {st }}$ century (Professional Development Service for Teachers, 2017), in the second segment of the research, we examined students' expectations in relation to cooperation with professors and other students while preparing and performing integrative teaching of Literature and Science and Social Studies. The data were collected on the basis of a couple of statements, and the first one refers to the joint activities of teachers and students at different stages of studies within the frame of preparation and didactic transformation of the teaching content suitable for the realization of integrative teaching of Literature and Science and Social Studies. The largest number of students, i.e. 104 respondents (69.33\%), expect cooperation with the subject teachers, as well as with older and younger colleagues from the faculty during the preparation and realization of integrative teaching classes, believing that this may have motivational effects.

Basically, an integrative approach represents cooperation and students' willingness to cooperate, because they are directed to one another at all stages of planning and implementing an integrative approach to the curriculum. An integrative approach encourages students to exchange ideas, mo- 
tivate each other to access specific tasks with greater freedom, to find the best solutions when it comes to content, methodology and teaching resources. A critical analysis of both the proposal and the realization of the lessons of integrative teaching is equally important. During the preparation of an integrative approach, students conduct research together and make a selection of the teaching content; explore various types of texts: literary, literary and scientific, scientific and popular, informative, textbook, etc.; they search for functional models of their combination and a productive teaching methodology, as well as teaching tools that will enable successful realization. The fact that students are engaged in the implementation of an innovative approach enhances the need for support they provide to each other during the realization and evaluation. Other interested students may also be involved in the process, thus giving them the incentive to engage in what they may not have thought about. For this exact reason, for the purpose of their future work, students' attention is drawn to the fact that, regardless of the degree of accomplishment, the primary goal of cooperation of various methodologists in a common educational task is the integrated development of academic and communicative competences.

On the one hand, in the light of improving the quality of university education, the focus of the teaching process should be transferred from the teacher and teaching content to the students and their needs, and, on the other hand, to the quality of knowledge and skills acquired during the education process (Kennedy, 2007). Accordingly, the third re- search task was to examine the attitudes of the students of the Faculty of Education in Jagodina about the influence of integration of methodological approaches of Literature and Science and Social Studies teaching on the quality of the acquired knowledge. The obtained data indicate that the majority of students (130 of them which represents $86.67 \%$ of the total number of respondents) believe that this methodological process enables the acquisition of high quality knowledge that can be applied in new, different situations, especially when selecting and didactically transforming texts that can be used while working with elementary school students during the classes of Science and Social Studies. Integrative teaching includes the creation of meaningful connections between similar elements of the curriculum of various disciplines in order to enable examination of all the various dimensions of a certain problem. The aim of integrative curriculum teaching is to examine the studied phenomena from the perspective of different teaching and educational areas. Thus, the phenomena are presented and experienced in a complex and versatile manner (Rosandić, 2005), and the acquired knowledge is better.

On the other hand, the majority of students (= 134, i.e., $89.33 \%)$ believe that the integration of content of different subjects encourages students to actively participate, enabling them to more comprehensively examine phenomena and processes from different perspectives (Figure 2). This certainly contributes to the acquisition of the high quality and long-term knowledge that can be successfully applied in practice. Content, knowledge and compre-

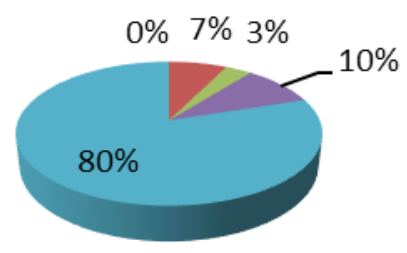

Completely Disagree Do not agree Don't know Agree Completely Agree

Figure 2. Distribution of Students' Responses Related to the Statement Regarding the Impact of Literature and Science and Social Studies Content Integration on Student's Knowledge Quality 
hension are "taken" from one discipline in order to be enriched and applied in another, in which way different perspectives are taken into account, facts are interconnected, ideas discussed critically and creatively, while content is experienced and their own original works examined and discovered in diverse ways (Åström, 2008). Therefore, 127 respondents $(84.67 \%)$ believe that students should be enabled to study certain content through an integrative approach and in the context of ambient teaching, in order to gain better knowledge. Twenty students had a neutral attitude on this issue, and only three students reported a negative attitude (Figure 3 ). The application of integrative teaching is of great importance since the content of various subjects logically connected in a single system is easier, faster and better to acquire (Spasić-Stošić, 2014). The new organizational model of the educational process is based on linking related subjects to a common didactic system. An integrative approach enables not only the acquisition of certain knowledge in individual subjects, but also the development and improvement of numerous habits and abilities of students that are important for their future vocation.

The confirmation of the thesis that the content and knowledge from one discipline enable a better understanding and easier acquisition of the content from another discipline in integrative teaching, can be found in the possibility to establish a link between the social and historical circumstances and the thematic and motive-related content, as well as the conceptual meaning of a literary piece, facilitating their deeper understanding. The design and understanding of the context in which historical and social phenomena occurred enables a more comprehensive reception and emotional experience of a literary piece written in the same social and historical circumstances. For instance: findings related to the difficult life of the Serbian people under the rule of the Ottoman Empire can point to the causes of the emergence of Hajduk groups and the primordial desire to regain the lost freedom and empire through fighting, but also provide a basis for understanding the actions of Old Vujadin, a hajduk who is a symbol of a steadfast decision that the given word of promise and the oath must not be broken even at the cost of losing life. On the other hand, the autobiographical narratives of Mihajlo Pupin, Milutin Milanković and Nikola Tesla, analyzed during the Literature classes, as part of the teaching units about famous figures in the history of the Serbian people, will provide an opportunity for students to learn about their

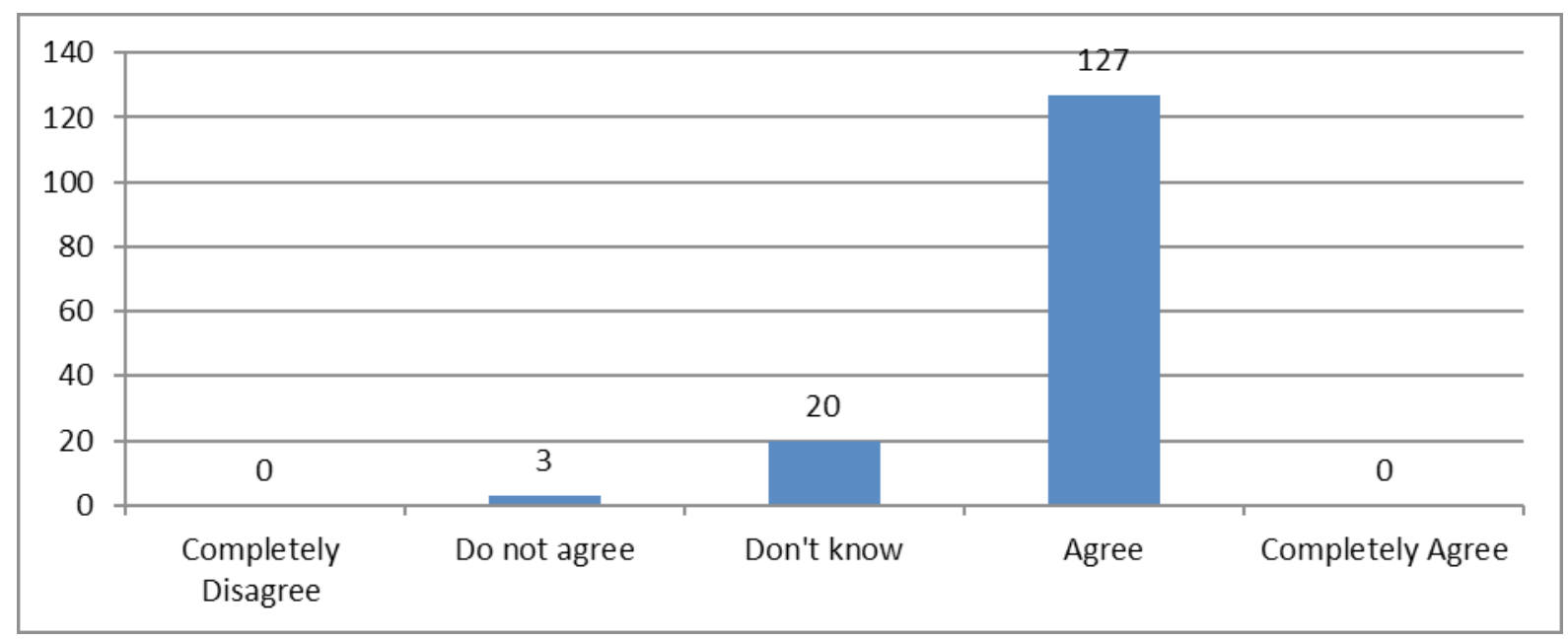

Figure 3. Distribution of Students' Responses Related to the Statement on the Application of Integration in University Teaching 
life in a convincing manner, as of people who grew up and were tormented by similar doubts and queries as students of today. Students will experience and acquire the significance of the reforms and collecting and publishing folk poems and stories by Vuk Karadžić in a more comprehensive way based on a story on the social and historical circumstances in which Vuk struggled and worked. Science and Social Studies content about the social state of affairs in Serbia at the time of the First and Second Uprising can be vividly illustrated by Vuk's ethnographic and historiographic records.

These are just some of the examples of content integration that point to the importance of the context as a good basis for a more complete reception and emotional experience of literary pieces and, on the other hand, literary and scientifically popular texts that illustrate historical events and their participants in a convincing and picturesque way. Literary works are more comprehensively comprehended and perceived if they are considered in the context of the social and historical circumstances in which they were written. Successful reception of a literary piece, on the other hand, sheds light on the social and historical situation, and the interpretation of procedures, psychological states, thoughts and emotions of the characters of literary texts provides an opportunity to experience them, even though historical figures, as people who went through their ups and downs, troubles and joys. The need to detect and highlight the relationships between all the mentioned elements and interpret their nature provokes active participation in the teaching process and the realization of educational and functional tasks of teaching. Consequently, it is expected that students acquire functional knowledge, develop key competences and therefore secure their place in the labour market (Lungulov, 2011), because modern society employs those who are able to cope with the multidisciplinarity of a job position and those who are proficient in information technology. Nevertheless, the importance of social and emotional skills and the ability to communicate and understand others, as well as exhibit responsible attitude towards one's own health, the health of others in the environment is becoming more and more appreciated every day (Binkley et al., 2012).

\section{Conclusion}

An integrative teaching approach undoubtedly has its own advantages, yet the application of this didactic system requires considerable creativity and expertise on the part of a teacher. Such a system should contribute to a better understanding and gradual comprehension of certain content, thus demanding a high-quality teacher who is familiar with modern methodological trends and knows how to apply them in their teaching practice. Faculties of Education are expected to provide for students - future teachers the prerequisite conditions for the acquisition of necessary competences to plan and realize integrative classes through quality university education, because the results of this research point to the following conclusions: students of the Faculty of Education recognize the benefits of integrative teaching and acknowledge its importance for their future professional engagement; students expect to cooperate with professors and other students in the process of preparation and realization of integrative classes; they likewise define the integration of methodological content as the premise of quality related to the acquired knowledge at the faculty, seeing it thus as one of the preconditions for a better understanding of the content adopted during the teaching process.

In line with the aforementioned claims, we believe that the integrative teaching model should take its place in the system of university teaching at the faculties of education, in order to enhance its quality. 


\section{References}

- Aristya Putra, P.D., Kumano, Y. (2018). Energy Learning Progression and STEM Conceptualization Among Pre-service Science Teachers in Japan and Indonesia, The New Educational Review, Vol. 53/2018, 153-162.

- Åström, M. (2008). Defining integrated science education and putting it to test. PhD Thesis, Linköping University, Sweden, Faculty of Educational Sciences.

- Banjac, M., Vilotijević, M. (2009). Uvod u metodiku nastave prirode i društva. Banja Luka: NOBIN- NEI.

- Barth, R. S. (1999). Improving Schools from within. San Francisco: Jossey-Bass.

- Binkley, M., Erstad, O., Herman, J., Raizen, S., Ripley, M., Miller-Ricci, M., \& Rumble, M. (2012). Defining Twenty-First Century Skills. In P. Griffin, B. McGaw, \& E. Care (Eds.), Assessment and Teaching of 21st Century Skills (pp. 17-66).

- Blagdanić, S., Banđur, V. (2018). Metodika nastave prirode i društva. Beograd: BIGZ i Učiteljski fakultet Univerziteta u Beogradu.

- Bodroski Spariosu, B. (2015). Univerzitetsko obrazovanje - od Humboltovog modela do Bolonjskog procesa. Nastava i vaspitanje, LXIV, 3, 407-420.

- Buljubašić-Kuzmanović, V. (2007). Studentska prosudba učinkovitosti integrativnog učenja. Odgojne znanosti, 9 (2), 147-160.

- De Zan, I. (2005). Metodika nastave prirode i društva. Zagreb: Školska knjiga.

- Forsman Svensson, P. (2004). The Bologna Process at the University of Helsinki Language Centre (HULC). Retrieved January 4, 2019 from the World Wide Web http://www.helsinki.fi/kksc/cercles04/Pirkko_Bologna. pdf

- Jevremov, T., Lungulov, B., Dinić, B. (2016). Zadovoljstvo studenata kvalitetom nastave: efekti godine studija i akademskog postignuća. Nastava i vaspitanje, LXV, 3, 491-508.

- Kennedy, D. (2007). Writing and Using Learning Outcomes. Cork: University College Cork.

- Landi, G. K. (2007). Zainteresujte đake za učenje. Beograd: Kreativni centar.

- Leisyte, L. \& Westerheijden, D. F. (2014). Stakeholders and Quality Assurance in Higher Education. In H. Eggins (Ed.), Drivers and Barriers to Achieving Quality in Higher Education (pp. 83-98). Rotterdam: Sense Publishers.

- Lisbon European Council 23 and 24 March 2000, http://www.europarl.europa.eu/summits/lis1_en.htm

- Lungulov, B. (2011). Ishodi učenja u visokom obrazovanju kao indikatori kvaliteta obrazovanja. Pedagoška stvarnost. 57, 7-8, Novi Sad: Savez pedagoških društava Vojvodine.

- McKimm, J. (2009). Teaching Quality, Standards and Enhancement. In H. Fry, S. Ketteridge, \& S. Marsha (Eds.), A Handbook for Teaching and Learning in Higher Education (pp. 186-197). New York: Routledge.

- Miller, M., Boix Mansilla, V. (2004). Thinking Across Perspectives and Disciplines, Interdisciplinary Studies Project, Project Zero. Cambridge, MA: Harvard Graduate School of Education.

- Mirić, M., Đorović, D. (2015). Nastava stranih jezika na univerzitetu: saradnja nastavnika jezika struke i nastavnika stručnih predmeta, Nastava i vaspitanje, 64(3), 507-520.

- Mirić, M., Đorović, D. (2013). Jezik struke na univerzitetu: stavovi nastavnika stručnih predmeta. U I. Lakić i N. Kostić (ur.), Kroz jezike i kulture, Zbornik radova sa Treće međunarodne konferencije Instituta za strane 
jezike i Treće međunarodne konferencije o interkulturnoj komunikaciji (str. 481-488). Podgorica: Institut za strane jezike Univerziteta Crne Gore.

- Regulations on Continuous Professional Development and Academic Title Reception for Teachers, Educators and Associates („Sl. glasnik RS“(Official Gazette RS), no. 13/2012 i 31/2012\). Professional Development Service for Teachers, 2017.

- Qiang, Z. (2003). Internationalization of Higher Education: Towards A Conceptual Framework. Policy Futures in Education, 1 (2), 248-270.

- Satiansiriwiwat, S., Intorrathed, S., \& Siriwan, S. (2018). Integration of Agricultural Knowledge with the Thai Language, Mathematics, and Science Subjects for First-year Elementary School of Thailand, The New Educational Review, Vol. 51, 41-52.

- Sawyer, L. B. \& Rimm Kaufman, S. E. (2007). Teacher collaboration in the context of the responsive classroom approach. Teachers and Teaching: Theory and Practice, Vol. 13(3), 211-245.

- Spasić-Stošić, A. (2014). Korelacija nastavnih predmeta Svet oko nas i Srpski jezik u I razredu osnovne škole. Godišnjak Učiteljskog fakulteta u Vranju, knjiga V, 499-509.

- Strategy of Education Development in the Republic of Serbia until 2020 (2012), Službeni glasnik RS (Official Gazette RS), no. 107/2012.

- The Bologna Process 2020 - The European Higher Education Area in the New Decade (2009). Communique of the conference of European ministers responsible for higher education, Leuven and Louvain-la-Neuve, 28-29 April 2009, Retrieved October 2, 2018 from the World Wide Web http://media.ehea.info/file/2009_ Leuven_Louvain-la-Neuve/06/1/Leuven_Louvain-la-Neuve_Communique_April_2009_595061.pdf

- Tošić Radev, M., Pešikan, A. (2017). „Komadić koji nedostaje“ u procesu obrazovanja: socioemocionalno učenje. Nastava i vaspitanje, 66(1), 37-54.

- Van Naerssen, M. \& Eastwood, S. (2001). CSE and teachers of english to speakers of other languages: A call for greater collaboration in teaching scientific reporting. Science Editor, Vol. 24 (1), 3-6.

- The Law on the Fundamentals of the Education System (2017), Službeni glasnik RS (Official Gazette RS), no. $88 / 2017$. 


\section{Оливера Цекић-Јовановић \\ Снежана Марковић \\ Универзийей у Країујевиу, Факулиеией йеgаїошких наука, \\ Јаїоgина, Реӣублика Србија}

\section{МОГУЋНОСТИ УНАПРЕЪЕЊА УНИВЕРЗИТЕТСКЕ НАСТАВЕ - ИНТЕГРАЦИЈА МЕТОДИЧКИХ ПРИСТУПА НАСТАВЕ КЊИЖЕВНОСТИ И ПРИРОДЕ И ДРУШТВА}

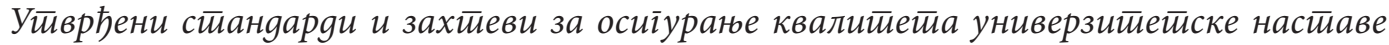

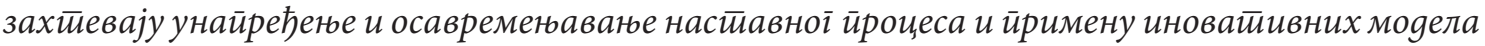

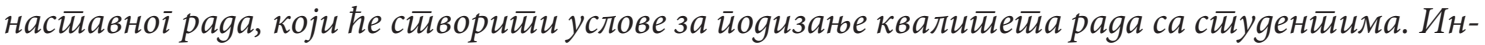

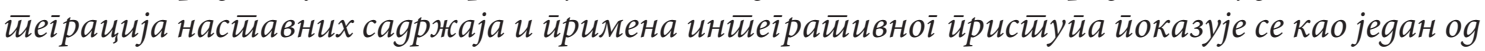

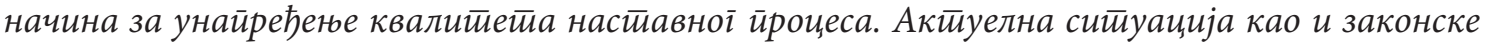
реіулатииве које јасно истиччу значај иниетіратиивне настиаве неминовно йовлаче за собом и

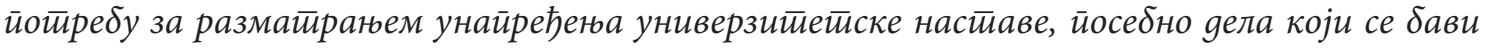

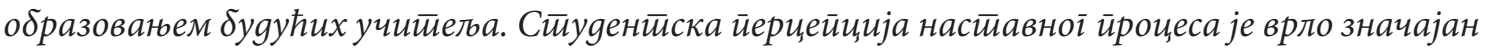

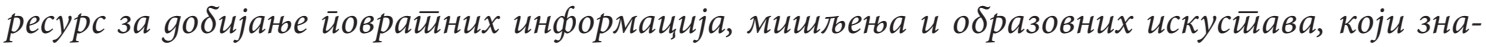

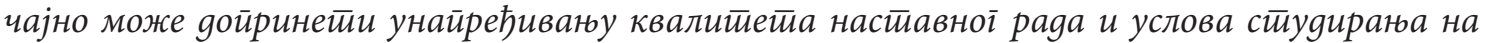

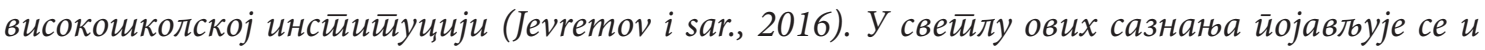

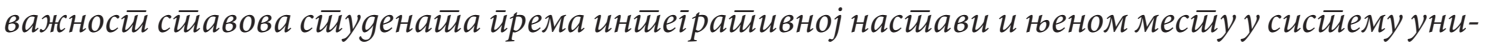

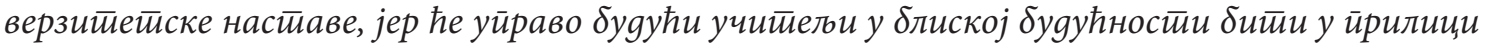
gа реализују настиаву у склаgу са Законом о основама сисиема образована и васииитана (Zakon o osnovama sistema obrazovanja i vaspitanja, 2017).

У овом раяу ӣреgстиављен је ӣример инйеірације насииавних саяржаја Мейоgике

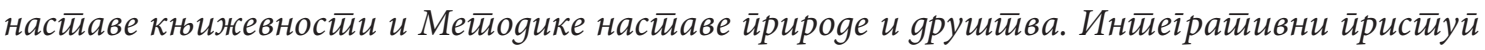

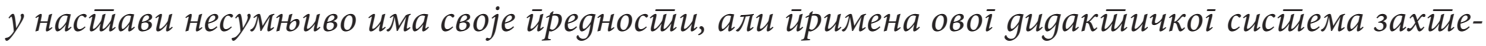

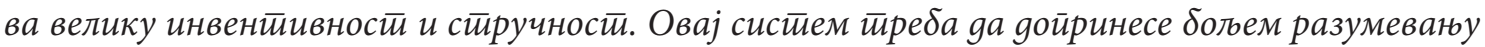

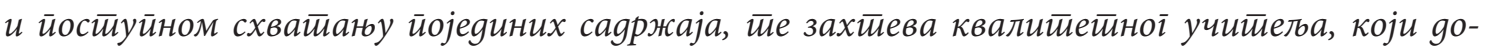
бро йознаје савремене метиодичке йендениије и зна како gа их иримени у својој настивној иракси. Да би се тиеоријски конйексти развоја ове ияеје ӣретиочио у ирраксу, реализована је

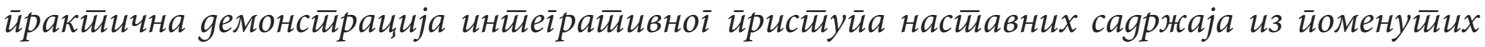

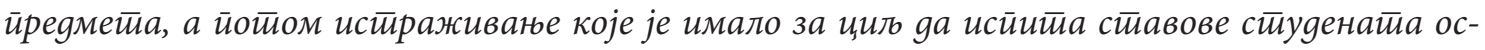

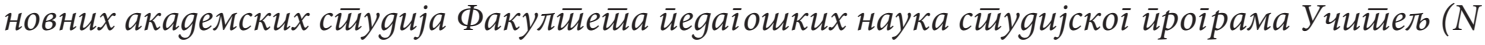

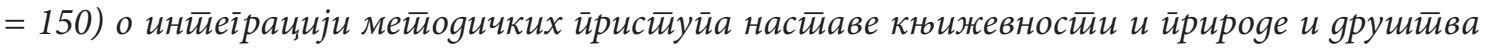

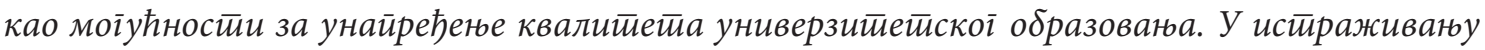

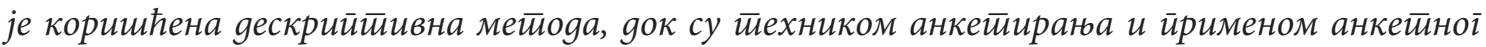

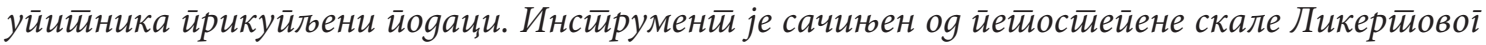

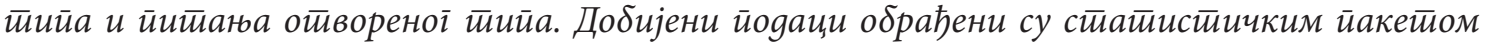
IBM SPSS Statistics 20, а у склаgу са ироучаваним иреgметиом, коришћеном метиоgом и ин-

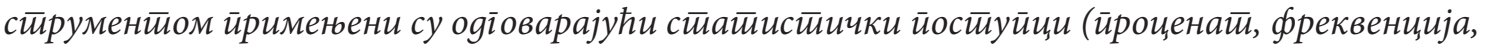
медијана). 


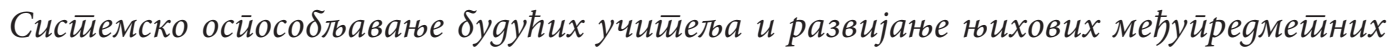

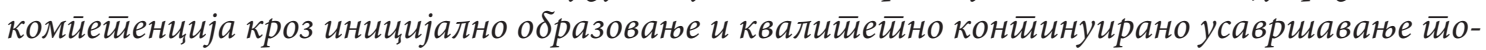

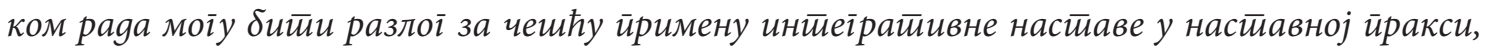

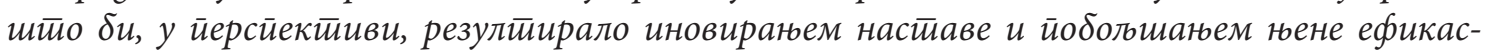

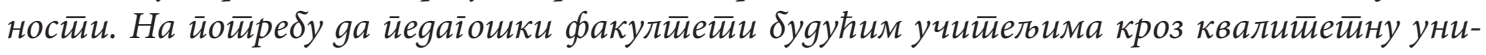

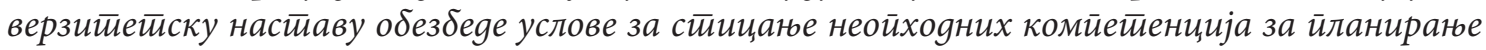

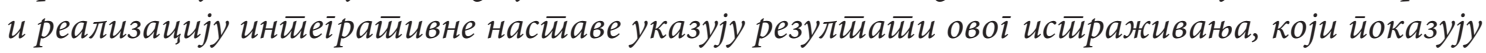

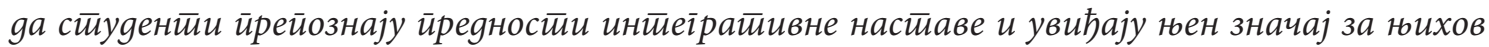

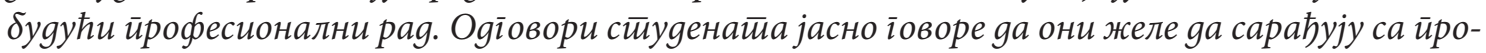

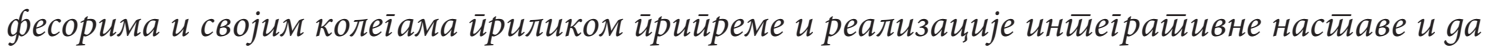

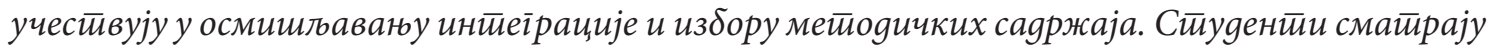

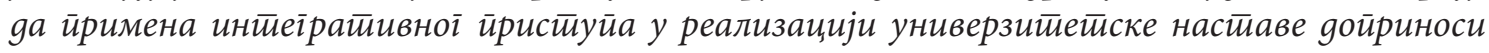

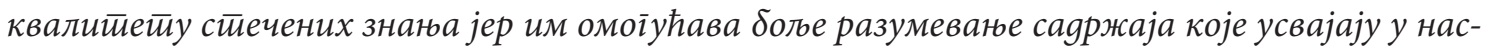

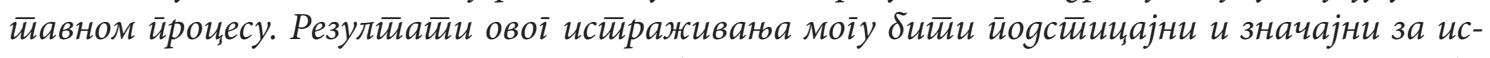

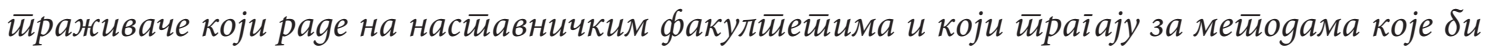

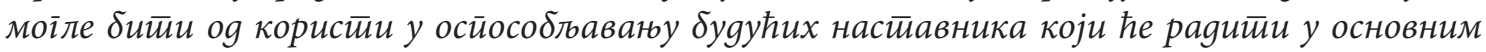
школама, а gуїорочно уйицатии на унайређене образовноі систиема у Србији. Такође, ови

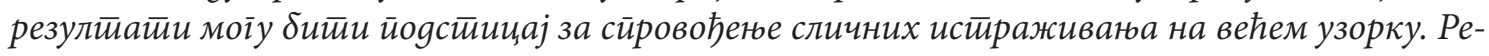

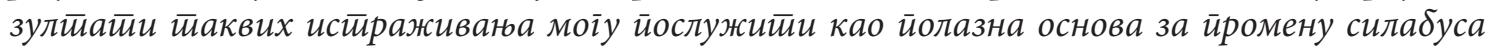

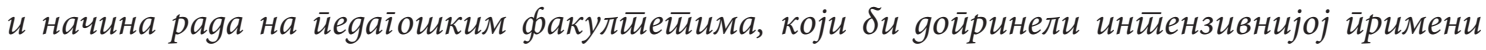

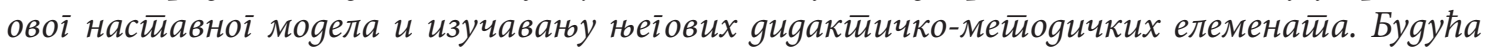

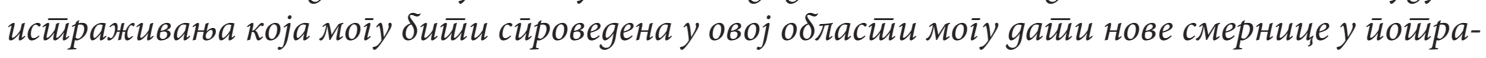

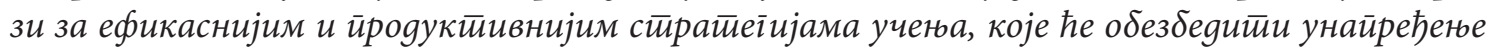
настиявної йроиеса.

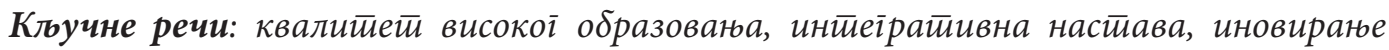

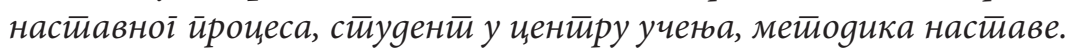

